\title{
Electronic Governance and Service Delivery in Selected Ministries in Ebonyi State, Nigeria
}

\author{
Omebe Matthew Amuche \\ Department of Public Administration Enugu State University of Science and Technology, Nigeria
}

Received: 24 April 2019; Revised: 22 May 2019; Accepted: 6 June 2019; Published: 2 July 2019

\begin{abstract}
The main objective of this study is to find out the extent electronic governance facilitates service delivery in Ebonyi State Bureaucracies. In specific terms, the objective of this study is to: Find out the extent the adoption of electronic governance aids record keeping/tracking of events in Ebonyi State Bureaucracies/Ministries; Examine the extent the adoption of electronic governance encourages accountability and transparency in Ebonyi State Bureaucracies/Ministries and Determine the extent the adoption of electronic governance encourages quality service delivery in implementing the projects and programmes of Ebonyi State Bureaucracies/Ministries. The theory adopted in this research is the Theory of Innovation and Diffusion propounded by Everett Rogers (1957). This theory tries to elucidate the implication of Technology/ Internet in the various spheres of life in the contemporary society. The research design adopted is a descriptive survey design. The instrument used in generating data in the study is questionnaire. The following are some of the main findings made in the study: Electronic government makes an impact on the knowledge of the society as well as on the literate level of the society. Electronic governance is very beneficial to the people who have electricity. The adoption of electronic governance in running the affairs of the ministries brings about effective service delivery in the state. It helps in defining and re-defining the current vision and mission of the government. The adoption of electronic governance curtails the level of corruption and encourages accountability and transparency in governance since it is a mechanism for carrying out proper internal and external auditing in government. The adoption of electronic government in Bureaucracies helps in facilitating the formulation of strategies for project and programme implementation in the states. The research has the following recommendation: The government of Ebonyi State should adopt therefore electronic governance in order to institutionalize in the state for real budget tracking in the state. Government should adopt the use of electronic governance in the state since it brings about significant improvement in governance through accountability and transparency; detects and prevents poor service delivery, curtails unnecessary waste, as well as arbitrary and captious behavior in Bureaucracies. Government should employ both qualitative and quantitative manpower who are experienced in the electronic governance in the Bureaucracies so that the programmes and projects of the government will always be effectively and efficiently carried out.
\end{abstract}

Keywords: Governance, Electronic administration, Bureaucracy, Programme

\section{Introduction}

Sequel to the Social Contract existing between the people and the government, it has become imperative that governance, remains an indispensable medium through which the various needs of the citizens are met with, (Okoli,2013, p.17). In other words, governance has become a means of rapid development to people across the board. However, the extent in which the government meets the needs of the people and spread development across the board largely depends on the type of governance adopted and practiced in the country.

No doubt, some countries have been practicing an analogue form of governance, and the actors could not deliver on the mandate. Consequent upon this, therefore, the need to embrace a digital form of governance, other-wise called 'electronic governance' became imperative. In the specification, the concept of e-governance began in the early 1990s, and it first gained popularity in the U.S.A, as the 1998 Government Paperwork Elimination Act drove it, formally introduced by the former President Mr. Bill Clinton on December 17, 1999, (Abdulkareem, 2015). Be that as it may, different countries have gradually taken after the United States of America and adopted e-governance, (Dode, 2007). According to Agbo (2014, p.1), Information Communication Technology (ICT) has grown tremendously around the globe particularly in the developed nations of the world. According to Dawes (2008), digital information has exploded in volume and diversity. It is created, 
shared, and used in myriad ways that can generate both public and private value. Communication networks span the globe, allowing individuals, groups, and organizations to interact regardless of time or location.

As Akunyili (2010), puts it, Nigeria joined the global train of ICT like most developing countries as a consumer of the technologies particularly in the areas of personal computers and digital electronics. For Danfulani (2013), the implementation of e-governance in Nigeria was made possible with ICT revolution, which according to Ojo (2013), kicked off at about two decades ago, when the country, rapidly got evolved in Information Communication Technologies (ICTs) and permeated nearly every aspect of government, business, and daily life. Particularly, in the words of Abdulkareem (2015), the Federal Government of Nigeria actually recognized the need to transform the public service into the modern day system through the use of Information Communication Technology in the year 2000. For Abdulkareem (2015), it is an IP-based virtual private network based on broadband technology introduced in April 1998 and further upgraded in February 2004.

As a matter of the fact, other tiers of government got interested and joined the bandwagon. Meanwhile, the entire process started like a pilot scheme by some ministries and parastatals at the federal level. Sequel to its acceptance, therefore, e-governance became a fairly broad subject matter, which has changed the way services and representation are delivered and how they are being implemented in Nigeria. With the deregulation of the sub-sector and direct capital investment by foreign firms, the country experienced a quantum leap and overtook all other countries in the continent principally because of the largeness of the population which is roughly put at about 170 million people and the share wealth of the nation which gave a sizeable number of the citizens and governments at the three tiers of authorities the capacity to buy Personal computers, Smartphone, and other internet related appliances and run internet programmes that integrated governmental ministries and departments (Akunyili,2010). Because of this massive growth in communication and the virginity of the market in Nigeria has become a preferred destination of international telecommunication investors from Asia, Mideast, South Africa and Europe (Adeyemo, 2010).

In line with the growing reality and to move along with the global drift, the Federal Government of Nigeria (FGN) adopted a national policy on Information Technologies and is prepared to integrate Agriculture, Health, and Education, etc. Meanwhile, the Federal Government of Nigeria launched data and research satellite in 2003. The development and the provision of other sundry policies rolling in the pipe, indeed set Nigeria on the path of countries exploiting ICT for governance. And more government parastatals, ministries, and departments are could now communicate within and outside their organizations, using echannels of communications. Before, the structure emulated private-like business techniques. Recently, that has all changed as e-government begins to make its own plan. Not only does e-government introduce a new form of record keeping, it also continues to become more interactive to better the process of delivering services and promoting constituency participation. Notably, the framework of such organization is now expected to increase more than ever by becoming efficient and reducing the time it takes to complete an objective as it concerns: paying utilities, tickets, and applying for permits. To help, administrations are now trying to aid those who do not have the skills to fully participate in this new medium of governance, especially now that government progress to more e-governance terms and conditions.

It is therefore, obvious that the overhaul process of the government structure, targeted to suit the internet system, where every pre-existing sub-entity merge under one concept of e- government is on top gear. As a result, Public Policy has now seen some changes due to the emerging of constituent participation and the Internet. It is, however, important to note that the government of many countries like that of Canada began to invest in developing new mediums of communication of issues and information through virtual communication and participation.

More importantly, e-governance aims to help strengthen government's drive towards effective governance and increased accountability and transparency for better management of resources, growth and development. E-Governance has consequently become an accepted methodology involving the use of Information Technology in improving transparency, providing information speedily to all citizens, improving administration efficiency and improving public services such as transportation, power, health, water, security and municipal services (RadhakrishnanHYPERLINK "http://ezinearticles.com/?expert=Thara Radhakrishnan", 2006) in (Ojo, 2013). Hence, E-governance is a political device adopted to ensure good governance at any level through which government and citizen's relationships are facilitated to ensure effectively and efficiency service delivery. For all countries resolved to fight poverty and accelerate overall social and economic development, the implementation of e-governance can make a valuable contribution. It can help to create new jobs, foster the development of business, enhance

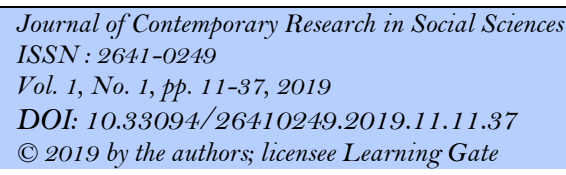


citizens' participation in decision-making and improve the efficiency of government services. In that sense, egovernance can contribute to capacity-building in Africa, improve the accountability of governments and enhance citizens' trust in them (UNESCO, 2007).

Notably, globalization has further diffused that division is unlimited potential through which rural areas can achieve sustainable, self-reliant, localized economy. Participation of private and public actors will stimulate the process of governance while trust and accountability factors will harness ICT empowered stakeholders. Such is only possible if the weaker side of the equation is given adequate resources (water, power, land, sanitation) and is provided with standardized services across the board. Barriers to minimizing the divide would lay largely with agency and bureaucracy intervention as well as capitalist corporate gains through unfair means. Ethical and good e-governance is the only sustainable solution in an ICT enabled urban and rural environment (Hina, 2007). No doubt, the application of e-governance has been a potent instrument in disseminating information, consultation, enhancing Citizen's participation, and sending feedback to the citizens, monitoring and evaluating government projects and making government accountable and transparent in its total political engagements. E-governance has become a necessary political mechanism in evaluating government performance in many developed nations of the world, including United Kingdom, U.S.A, Netherland, Germany, etc; it enhances citizen's ability to have access to the basic programmes of government while it brings about openness in performing public functions.

According to World Bank (2011), e-governance involves the use of new technologies that can serve a variety of different end: better delivery of government services to citizens, improved interactions with business and industry, citizen empowerment through access to information, or more efficient government management. The resulting benefits can be less corrupt, increased transparency, greater convenience, revenue growth, and/or cost reduction.

\subsection{Statement of Problem}

The switch from analogue to electronic governance is an important move, which bridges the gap between government and the people, (Ojo, 2013). The movement, however, appears to be relatively slower in the developing nations including Nigeria. Due to the slow application of e-governance in Nigeria, certain setbacks are therefore, observed in the Civil Service in Nigeria and Ebonyi State in particular. One of the setbacks in the implementation of the electronic governance in Nigeria is inadequate accountability and transparency. Due to what seems to be inadequate accountability in the civil service, the application of electronic governance seems to be difficult. Although money could be allocated for the procurement of the necessary equipment and even training of staff for the application of the e-governance due to fraudulent use of the money and officials not being accountable and transparent jeopardizes the whole thing from time to time.

In another dimension, there appears to be lack of accountability and transparency in the Civil Service due to slow in the application of e-governance in Nigeria and Ebonyi State in particular. According to Jaja (2012), lack of accountability and inadequate transparency hinder the application of electronic governance in the state. What appears to be the weak financial muscle of government at the various level of authority, therefore, seems to be a serious challenge bedeviling the adoption of e-governance in Nigeria and in Ebonyi State specifically. Different public organizations in Nigeria fall short of the fund as a result of bureaucratic and financial corruption among officers, (Johari, 1989:280). At the risk of oversimplifying some development in introducing or improving practical measures to safeguard integrity, transparency and accountability within regions can also be noticed, (Amstrong, 2005). The development within the regions demonstrates that despite their differing geo-political and cultural situations, the administrations face similar challenges. The challenges include age-old role conflicts of public servants as they navigate between the obligations of their public office and private interests and a better-informed public, demanding more voice and responsiveness from the government. This appears to lead to financial mismanagement and lack of accountability.

Another challenge facing the ministries in Nigeria, and Ebonyi States in particular, is what appears to be in proper record keeping method in the civil service. According to Cyrille (2010), recordkeeping in the present day offices are not designed and operated in such a way that it will meet the information need. According to him, record system even in computer suffers a high rate of missing and misfiled record due to inadequate application of the electronic-record-keeping method. Notably, the emergence of electronic records in record management poses a big challenge to record officers in the area and use of the internet, microfilming, and microfiche. The challenge is the ability to harness the physical documents and electronic records, and the ability to use them as important tools of value in the future.

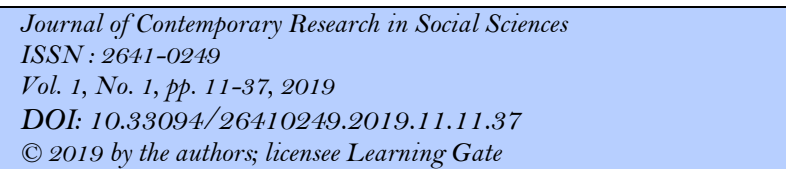


Therefore, poor records management creates information gaps that that results in inadequate records and loss of documents. For Okofian (2012), any document that could not be found at a time is as good as lost. Of course, time lost in the search for records that cannot be found, affects public service, adversely. To this effect, Nwoba (2015), states that one of the problems facing Ebonyi State in its developmental stride is its unorganized record management systems in the MDAs. In his words, Nwoba (2015), posits that this poor record management system in public service impaired decision making, due to unavailability of records caused by misplacement or missing records. In another dimension, there seems to below quality service delivery in the ministries in Nigeria due to low commitment to duties by the officers in the service. The problem appears to be that government does not seem to be ready to employ individuals who are dedicated and capable of delivering quality service. That seems to shorten the expertise desirable to make use of the ICT facilities and deliver quality services in the Civil Service, (Danfulani, 2013). In some cases however, the employed staff who are ready to deliver quality service are not allowed by some top officials in the offices. Sometimes, they are under placed or replaced with those who do not care about quality service, and as such, to corrupt top officials, tend to have the free opportunity to oversee every affair, especially the financial affairs in the offices. By so doing, attention is concentrated on the embezzlement of the fund rather than on quality service delivery.

For a French Jurist, Baron Montesquieu (1748) in Okoli (2015:125), there would be an end of quality service delivery in the state if the same person or body, whether of the nobles or of the people, were to exercise all the powers. According to John Locke as captured by Johari (1989), it has been a great temptation to human frailty who apt power for the same persons including the power to make and implement financial policies at the same time. This, plays down on quality service delivery in the Civil Service. Nevertheless, inadequate quality service delivery also occurs as a result of inadequate facilities, incentives for serious staff who are dedicated to duties and ready to deliver on the mandate, using ICT integration (Spodark, 2003). As Okey (1998) and Adeboye (2001), puts it, the attitude of the Nigerian Government in the provision of ICT infrastructure and facilities at the level comparable to the international standards has been generally lamented to be discouraging and a serious challenge to quality service delivery in the country.

\subsection{Objectives of the Study}

(I) Find out the extent the adoption of electronic governance aids record keeping/tracking of events in the Ministries in Ebonyi State.

(2) Examine the extent the adoption of electronic governance encourages accountability and transparency in the Ministries in Ebonyi State.

(3) Determine the extent the adoption of electronic governance encourages Service Qualityin Ebonyi State.

\subsection{Research Hypotheses}

The researcher adopted the following alternate hypotheses in this study:

Ha1.The adoption of electronic governance aid record keeping/tracking of events in the Ministries in Ebonyi State.

Ha2.The adoption of electronic governance encourages accountability and transparency in the Ministries in Ebonyi State.

Ha3.The adoption of electronic governance enhances Service Quality in the Ministries in Ebonyi State.

\section{Review of Related Literature}

\subsection{Concept of E-Governance}

E-government means electronic-governance and the word 'electronic' denotes the use of technology in the system of governance. Therefore, e-governance is the application of Information Communication Technology (ICT) for effective and efficient service delivery, exchange of information, communication transactions, integration of various stand-alone systems and services between government-to-citizen $(\mathrm{G} 2 \mathrm{C})$, governmentto-business $(\mathrm{G} 2 \mathrm{~B})$, government-to-government $(\mathrm{G} 2 \mathrm{G})$, government-to-employees $(\mathrm{G} 2 \mathrm{E})$ as well as back office processes and interactions within the entire government framework. According to the Daily news (August 2, 2013), e-governance is the application of Information and Communication Technology (ICT) to assist the government for efficient and meaningful delivery of government services.

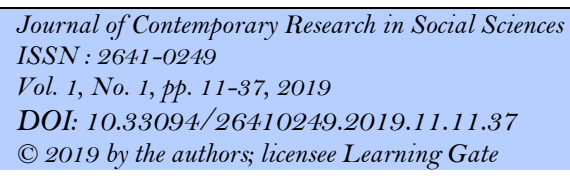


According to Ojo (2013), E-Governance is a wider concept that defines and assesses the impacts technologies are having on the practice and administration of governments and the relationships between public servants and the wider society, such as dealings with the elected bodies or outside groups such as not for profits organizations, NGO's or private sector corporate entities. E-Governance encompasses a series of necessary steps for government agencies to develop and administer to ensure successful implementation of egovernment services to the public at large (theinformationdaily.com). The figures/diagrams below show/depict the areas, aspects and scopes of e-governance clearer:

According to the United Nation's e-government survey (2004, 2005, and 2008), in Danfulani (2013), egovernment is the use of internet technology as a means of exchanging information, providing services and transacting with citizens, businesses, and other arms of government. According to Akunyili (2010), egovernment is the use of Information and Communication Technology to enhance access to, and delivery of government services for the benefit of all. E-governance is also defined as the process whereby the use of Information and Communication Technology and service are deployed and employed by the government in the delivery of services to members of the public and the use of same in the internal running and linkages among different government department and agencies. E-government is also the art of using tools offered by information technology in various aspects of the process of governance with the purpose of achieving efficiency, transparency, accountability and user friendliness in all the transactions that the citizens and business conduct with the government. E-governance is generally considered as a wider concept than egovernment, since it can bring about a change in the way how citizens relate to governments and to each other (Maswood, 2000). In the view of Akbar (2004), E-governance is the computerization and automation of common government processes with the goal of lowering costs, improving efficiency and generally providing better services to citizens.

According to Abdulkareem (2015), e-government is the use of information technology to improve governance, promote efficiency and effectiveness in the delivery of public service. It is the form of government adopted to facilitate an efficient, speedy and transparent process of disseminating information to the public, and other agencies, and for performing government administrative activities. E-governance is generally considered as a wider concept than e-government, since it can bring about a change in the way the citizens relate with governments and to each other. In the same vein, Backus (2001), adduces e-governance as the application of electronic means in the interaction between government and citizens and government and businesses, as well as in internal government operations to simplify and improve democratic, government and business aspects of Governance. E-governance is the application of information communication technology by the government to enhance accountability, creating awareness and ensures transparency in the management of governmental business. It is a political strategy in which the activities of government are made known through the adoption of modern communication technology.

Electronic governance involves interconnected interactions to deliver government products and services, exchange of information, communication, transactions and system integration. To that effect, Dawes (2008), states that e-governance involves the use of information and communication technologies (ICTs) meant to support public services, government administration, democratic processes, and relationships among citizens, civil society, the private sector, and the state.

According to Ojo (2013), e-governance is a medium for the delivery of government services and information to the public using electronic means, usually Information Technology, which is seen as the best way for the implementation of e-governance since it is always efficient, speedy, participatory, transparent, and affords accountability in disseminating information to the public and at the same time, better in performing government activities (Government Information Agency, Guyana).

\subsubsection{Concept of Service Delivery}

Service delivery means effectiveness and efficiency. In his words, Debo (2013:18), states:

People do not exist in isolation, be it family, organization, community, state, country or continent.

Whichever structure that brings the people together, throws up the need for a government. When the desired result favourable to the people is achieved, there is service delivery.

According to Okoli (2013), in what he referred to as Social Contract Theory, some group of philosophers believed that men, at a point in time, freely agreed to bind themselves under a government, and each person is duty bound to keep to the terms of this agreement. For government there must be the provision of the essentials to the people. When the government provides these essential needs of the people through its functionaries, service delivery has taken place. Maslow (1970), in Ezeani (2006), therefore, reviewedthat the

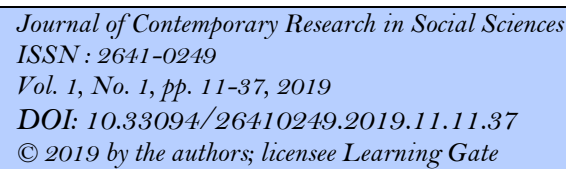


aspects/areas where government functionaries carry out service deliveryon the people are referred to as the five needs of man which include: Physiological; Security/Safety, Love, Esteem and Self-Actualization.

Theregular provision of these needs by government functionaries is what Maslow(1970), refers to as quality service delivery. This kind of service delivery must be regularly and adequately undertaken for the wellbeing of the individual citizens. The reason behind this is that government has it as its basic functionto intervene in a reasonable extent, into the private needs of the people to expand the area of human development/empowerment of the people, (Onyishi, 1996), in(Okpata, 2006). Other important areas government intervenes in the life of a manfor economic growth and development of the nation and quality service delivery are capacity building/human development and provision of Infrastructure.

According to Onah (2008), in a way to ensure quality service delivery, the human resources of a nation which comprise men and women, young and old, who are greatest, and indeed the most precious assets of the nation are allowed to experience the service delivery model which allows for training and provision of infrastructure and infrastructural facilities to the people. Nevertheless, for this delivery model to take its full course, e-governance comes into play. The adoption of electronic governance encourages quality service delivery in implementing the projects and programmes of Ebonyi state Bureaucracies/Ministries.

According to Onah (2010), physical assessment of the performance of projects and programmes involves comparing the actual use of labour and material inputs as against the estimates in the feasibility study made available. This comparison could be better done when e-governance is the order of the day. Very importantly, e-governance enables the government to understand the following concerning project and programme implementation and assessment in the state:

- Measurable objectives.

- $\quad$ Critical Assumptions

- Identification of indicators

- A data collection/recording system

- Analytical methods

- An effective organization structure.

According to Becker and Huselid (1998), in Armstrong (2009, p. 234), a high-performance work system is an internally consistent and coherent human resource management system that is focused on solving operational problems and implementing the organization's competitive strategy. Evaluating the performance of staff by the managements of the ministries helps to understand the true abilities/competencies of Human Resource, (Huselid et al, 1997). These occur in organization-related competencies reflecting on an understanding of the business and the implementation of the competitive strategy.

Today, one of the strengths of every ministry is the ability to have reasonable manpower that has moved from the analogue operation system to the digital operation system. Perhaps, increasing the number of manpower who can make use of the Information Communication Technology (digitalization and computer or internet-based activities) is key to quality service delivery in the project and programme implementation. According to Ezike (2014, p.1), the different ministries in Ebonyi State could embrace the superhighway and waves for subsequent development of Information Communication Technologies which brings about significant changes in the state.

Of course, there have been intimidating advances in magnetic storage technology; unequalled improvement in the processing speed and power of personal computers, and tremendous development of computer networks being experienced in the current times. According to Onah (2008), the human resources of a nation which comprise men and women, young and old, who engage in the production of goods and services and who are greatest, and indeed the most precious assets of the nation are to be provided with electronic facilities for them to be optimal in their service delivery.

\subsubsection{Service Delivery Model in E-Governance}

According to Agbo (2014, p.1), the adoption of e-governance is for effective service delivery. It can perhaps, be capital intensive; for instance, the cost of initial installation of an efficient ICT system in Nigeria usually exceeds the budget and as a result, it requires external assistance to adopt the appropriate ICT facilities. Interestingly, Nigeria can easily meet up with the financial challenges, being that the country has been rated one of Africa's strongest economy and the continent's largest market due to its population.

There are generally four basic/primaryservice delivery models/tracks available in e-government. They include: government-to-citizen (customer), government-to-employees, government-to-government and

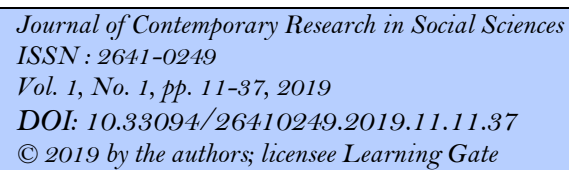


government-to-business. According to Danfulani (2013), in (Adeyemo, 2010), the four service delivery Model/tracks are Government-to-Citizen or Government-to-Customer (G2C); Government-to-Business (G2B); Government-to-Government (G2G) and Government and Government-to-Employee (G2E). Meanwhile, four sorts of activities take place within every of those four interaction domains (service delivery models)which occur in e-governance. They include:

i. Pushing data over the internet, e.g.: regulative services, general holidays, public hearing schedules, issue briefs, notifications, etc. two-way communications between one governmental department and another,

ii. Users' interaction in dialogue with agencies and post issues, comments, or requests to the agency.

iii. Conducting transactions, e.g.: Lodging tax returns, applying for services and grants.

iv. Governance, e.g.: This to alter the national transition from passive info access to individual participation. This happens in four ways, namely:

* Informing the individual

* Representing an individual

* Consulting an individual

* Involving the individual.

See Appendix one (1), figures: $6,8,9,10$ and 11 respectively.

\subsubsection{Stages of E-Governance}

E-governance metamorphosed from Information Communication Technology (ICT). In the words of Akunyili, (2010), Information and Communication Technology (ICT) is an umbrella term that covers all technical means for processing and communicating information. Meanwhile, the convergence of information technology (IT) and telecom technology gave birth to ICT, (Akunyili, 2010). Practically speaking, ICT finds expression in digital technology and all its uses and variants, including the computer, the internet, mobile telephony, the different electronic applications (e-banking, e-governance, e-commerce, etc), digital media and broadband technology.

\subsubsection{Essence/Justification of E-Governance}

Bellow is the essence/reason government could introduce electronic governance in the state:

\section{i. $\quad$ Preparation of the Present Generation for EffectiveWorkshop}

According to Matsepe-Csaburri (2003), one of the most commonly cited justification/reasons for the adoption of electronic governance has been to prepare better the present generation for a workshop where ICTparticularlycomputers, internet and technologies are becoming more and more ubiquitous. In the words of Okpata and Ukeje (2010), ICT has impacted greatly on effective research and other areas. For the United National Economic Commission for Africa (2001), ICT policies and strategies are essential tools to define Africa'sresponse to the challenges of globalization and nurture the emergence of an African Information Society.

\section{ii. To Support and Simplify Governance}

The strategic essence of e-governance is to support and simplify governance for government, citizens and businesses. It is to engage, enable or empower the citizen (UNESCO 2005). Others include making government administration more transparent, speedy and accountable while addressing the society's needs and expectations through efficient public services and effective interaction between the people, businesses, and government.

\section{iii. Good Governance}

According to Ojo (2013), the main purpose of implementing e-governance is to enhance good governance, which is generally characterized by participation, transparency and account-ability. Interestingly, the recent advances in communication technologies and the internet provide opportunities to transform the relationship between governments and citizens in a new way, thus contributing to the achievement of the goals of good governance. The major objective of information technology in governance, otherwise called 'e-governance' is to increase the effective, efficient and broad involvement of citizens in the process of governance at all levels by providing the possibility of on-line discussion groups and by enhancing the rapid development and effectiveness of pressure groups.

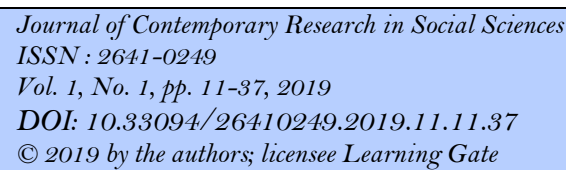




\section{iv. Improve Public Service Delivery, Transparency and Effective Dissemination of Information}

According to Abdulkareem (2015), the introduction of e-government was necessitated by the urgent need to improve public service delivery, ensure transparency, make government accessible, and ensure that information dissemination to the public is in real time. According to Danfulani (2013), the essence of egovernance is to bring revolution and allow the use of Information and Communication Technology (ICT) in governance.

E-governance also helps government functionaries toeasily find effective and efficient expression in digital technologies, using personal Computers with internet, having mobile and modern telephones, and getting deeply involved in different electronic applications in and outside their offices.

A confluence of technologies of course, makes the flow of information very easy, accessibility and quick in delivery. This is very important because citizens when government functionaries are fully connected globally through the internet, governance becomes more efficient and robust; the cost of governance and transaction will also be scaled down, and transparency will be enhanced.

\section{Improvement of Lives of People}

According to Akbar (2004), e-Governance aims to improve the lives of billions of people worldwide and to integrate government services in a way never seen before. As Akunyili (2010), puts it, a common objective of e-government is to automate or computerize all existing paper-based procedures to enhance access to, and delivery of government services to the citizens.

\section{vi. $\quad$ Integrating Government Ministries, Departments and Agencies}

E-government also aims at integrating government ministries, departments and agencies in a manner that promotes their on-line interaction (Akunyili, 2010). E-governance promotes linkage between government, business, nongovernment organizations, and other groups in society. E-governance as a reform strategy for improving the governance process could also improve the relationship between government and other groups in society, particularly the business sector. The business focus is in recognition of two things: its importance as a service provider to government's own needs and, at the same time, as a partner of government in responding to the needs of the public through outsourcing, given government's limited capacity; and the sector's apparent role in economic development.

\subsubsection{Importance/Benefits of E-Governance}

The importance of e-governance can never be over-emphasized. This is because Nigeria boarded the ship of e-governance like any other developing nation in the middle of the last decade, and since then, virtually all facet of life has experienced unprecedented transformation, (Ojo, 2013). The below are, therefore, the importance of e-governance:

\section{i. $\quad$ Record Keeping and Tracking of Events}

According to Okpata (2006:250), the Planning and Statistical Units is designated for record keeping as it works against the ignorance of individuals in the matters arising every day regarding the work activities in an organization. Meanwhile, it is the existence of e-governance that allows the system to keep all records in one easy location to update with every single bit of information that is relevant to a personal file. Examples include: social security numbers, tax information, current address, and other information. Common feature of e-government is the automation or computerization of existing paper-based procedures to enhance access to, and delivery of government services to the citizens.

Electronic records could help boost the local economy by attracting local and foreign tourists (Sier, 2005). Unwaifo (2004), therefore, posits that information recorded in both paper and electronic files help mangers, especially Chief executives to direct, control communicate, plan, formulate policies and make decisions. Accordingly, Cox (2001) described records as an extension of human memory, created to keep information, document transactions, communicate thoughts, substantiate claims, advance explanations, offer justifications and provide concrete evidence of activities

Sutcliffe (2003) submits that records are corporate memory capable of informing and restructuring all the activities of an organization. He further noted that records are to be recognized as a vital and reusable asset, source of content, context and knowledge. Ayeni (2000) contended that records are statements, facts, figures recorded in the form of impression and expression, purposely established for remembrance and reference.

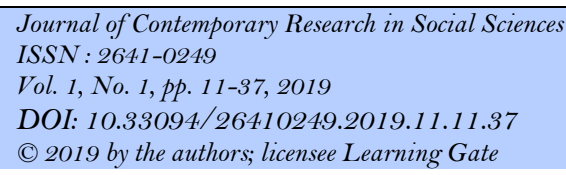


Atulomah (2011) affirmed that "without records, no assessment can be made of whether individuals and public organizations have carried out the actions and transactions that they had to execute, whether they have performed these actions and whether they have done the things which they were not supposed to do".

Longe (2000) presented an Information Management System as a file/records management programme that accesses internal accounting and production records to generate reports to various levels of management. Transaction Processes System that are sometimes called Operational Information System or Information and Communication Technology facility stores business information and controls the decision making aspect of records management. Robek, Brown and Stephens (1995) emphasized that effective records management programme in public service implies upgrading the records keeping system for easy and timely retrieval of information to improve office efficiency and productivity. It is on this background that the researcher is studying the status of records management in Ebonyi State Public service.

Sebina (2004) opined that good governance is enhanced through the adoption of functional records management and the entrenchment of freedom of information legislation by government. To that effect, Imeremba (2005), establishes that the adoption of Electronic Governance aids record keeping/tracking of events in Ebonyi State Bureaucracies/Ministries. Of course, there could be good data review when there is egovernance in a state. According to Onah (2008), data review as a result of e-governance opens up information dealing on projects and programmes of government for necessary actions. Perhaps, with e-governance, the following questions are better reviewed and answered:

- What is the activity carried out by the government?

- When should / is the activity to be executed?

- Who are to execute the activities?

- What are the other resources (material, technology and fund) for the execution of the activities?

- How long should the activity take place?

- What is the impact of the activities on the environment and the people concerned?

According to Ikeagwuani (2001, p.23), electronic record keeping allows the preservation of records for future uses. He therefore, adduces that such recordis usually:
i. Easy to access.
ii. Housed/kept in suitable equipment.
iii. Legible and properly indexed.
iv. Quick and simple to operate.
v. Specially designed considering the need of the department or office.
vi. Capable of expansion to meet the future needs of the organization.

Meanwhile, every record kept electronically is usually done in a particular/unique way. According to the National Records of Scotland (2013:2), they include:

1. Authenticity: the records must prove what they are purported to be and who created them

2. Accuracy: they would accurately reflect the transactions they document

3. Accessibility: they would be readily available when needed

4. Completeness: the records would be sufficient in content, context and structure to reflect the relevant activities and transactions that they document

5. Comprehensiveness: the records would st document the complete range of an organization's business

6. Compliance: the records would comply with any record keeping requirements resulting from legislations, audit rules and other relevant regulations

7. Effectiveness: the records would be maintained for specific purposes and the information contained in them must meet those purposes. Records also identify and link business process that are related

8. Security: the records would be securely maintained to prevent unauthorized access, alteration, damage or removal. They must be stored in a secure environment, the degree of security reflecting the sensitivity and temperature of the contents. Where records migrate across changes in technology the original evidence must be preserved and must remain authentic and accurate.

\section{ii. Accountability and Transparency}

When government provides room for openness in all its dealings through the open access information communication technology (OAICT), it promotes accountability and transparency in the management of

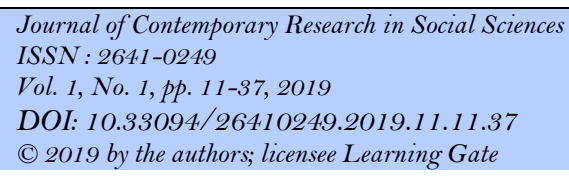


public affairs. E-Governance is a network of organizations to include government, nonprofit, and privatesector entities; in e-governance there are no distinct boundaries. According to Ojo (2013), e-governance brings about openness and transparency in the running of the governmental business. It is against this backdrop that this study examines e-governance as a fundamental political strategy through which the realization of sustainable grassroots development could be attained in Nigeria.

Through this process, multiple fraud dulent avenues of siphoning public resources by public servants like double payment of contracts and crowding of pay vouchers with ghost workers were blocked.Of course, much resource has been saved by the three tiers of government through implementation of e-governance. From the start of 1990s e-commerce and e-product, there has rampant integration of e-forms of government process. Governments have now tried to use their efficiencies of their techniques to cut down on waste, (Danfulani, 2013).

\section{iii. Research Development}

In the words of Emma (2006, p.2):

'Research is the most important tool for advancing knowledge, for promoting progress, and for enabling man to relate more effectively to his environment, to accomplish his purpose, and resolve his conflicts. Research is focused on the discovery of relationship that exists among the phenomena of the world in which we live. Research is devoted to finding the condition under which a certain phenomenon occurs and the condition under which it does not occur in what might appear to be similar circumstances.'

According to Genoni et al (2006), researchers could be positive regarding the usefulness of the internet for research purposes and for expanding their scholarly community. Kinengyere (2007), adduces that availability of information does not necessarily mean actually used. They do not know how to access them because they are not aware they exist or that they do not seek for them through research. It is therefore, the researchers who know the information existand seek for them who could use ICT to get result. In line with the above, Emma (2006, p.9), states that research serves a lot of purposes to mankind which include:

i. To gather, present and analyze data

ii. To distinguish opinion from facts

iii. To establish reliability and validityof theoretical postulations

iv. To add to our knowledge and social regularities

v. Contribute to building of theories

vi. T help us to know what we did not know before

vii. To provide researcher with the training in problem solving as well as in leadership rules

viii. To enable data bank, which helps in planning and development

ix. To help to train students for research related jobs with the academic profession etc.

Notably, the above purposes are better and easily achieved by a researcher who applies the ICT Method andfacilities in carrying out his/her research. This is because the exponential growth in information and knowledge seeking and the corresponding increase in user (researchers') need share stipulated a greater degree of technological invention and strategies towards the management, transmission/dissemination, and organization of information, (Bench, 2002). Of course, throughout the world, the internet has become allimportant technological tools in the production, marketing, and use of information worldwide (Nwuwa, 2014). In the words of Porta (2010), ICT can be used to extend access to education delivery techniques, to support the ongoing professional development of workers and facilitate education-related data collection and prolonging efforts in ways previously not possible.

Research can be said to have two purposes namely: intellectual and practical, (Obasi, 2000, p. 58). Aresearch may aim at one of these or both of them but whichever, the application of electronic governance strengthens it.It is aimed at advancing scientific knowledge through verification of hypothesis used to test theories. Pure (basic or academic) research is concerned with the seeking of knowledge for its own sake and to satisfy intellectual curiosity. It is based on the desire to know or understand.

\section{iv. Time, Energy and Financial Management}

According to Taylor (1947) in Nwizu (1999, p. 30), the transformation ofthe administration of the workforce for the increase in productivity demands amalgamation. That specialty, he called 'time and motion amalgamation.' This implies that for the workforce to effectively deliver on the mandate, such workforce needs to manage both time and motion, maximizing the both and making efficient production in the shortest period

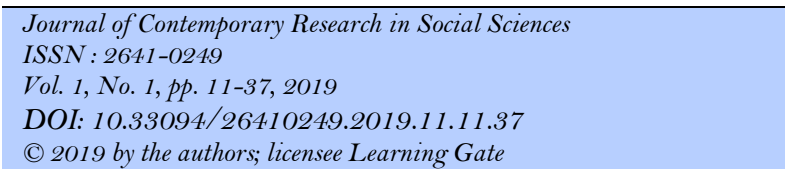


with little effort. Presently, the amalgamation of time and motion for effective service delivery could be better done using the ICT facilities/internet.

Of course,engaging on online activities like havingdiscussion forums or chat rooms to discuss policy issues; E-Meetings for cross agency/cross governmental participation; Online citizen surveys or polls for specific issues with published results; Online citizen satisfaction surveys with published results; Online Decision-Making - E-Petitions, E-Referenda; Online Performance Measures with published results save time, energy and money (Crowley, 2008). Moreover, the goal of government-to-citizen $(\mathrm{G} 2 \mathrm{C})$ in e-governance is to offer a variety of ICT services to citizens efficiently and economically, and to strengthen the relationship between government and citizens using technology, (Crowley, 2008). Put differently, e-governance is a process with different tasks which include: simplifications and speeding, procession of integration for electronic activities which include training of civil servants and harmony of e-services.

The above applications/activities are perhaps, facilitated and engineered by internet. To that effect, a lot of time, energy and money are saved. According to UNESCO (2005), government involves itself in e-governance for better time management, energy and financial management for effective and efficient service delivery. The transaction costs can be lowered and government services become more accessible in a very easy way. Notably, e-government is a one-way communication protocol whereas e-governance is two-way communication protocol.

The essence of e-governance is to easily reach the beneficiary and ensure that the services intended to reach the desired individual has been met with (UNESCO, 2005). As such, there could be an auto-response to support the essence of e-governance, whereby the Government realizes the efficacy of its governance. Egovernance is by the governed, for the governed and of the governed.The advantages therefore, are that government could provide better service, making adequate use of time, energy and financial management making governance more efficient and more effective.

Besides, the transaction costs can be lowered and government services become more accessible to the public at large. E-governance can easily and timely transform citizen service, provide access to information to empower citizens, enable their participation in government and enhance citizen's economic and social opportunities, so that they can make better lives, for themselves and for the next generation (www.saaritresources.com).

\section{v. Promoting of Participatory Democracy}

Another cherished goal of e-governance is greater citizen participation in the governance of the country (Barman, 2009). While ICTs have the potential to create a platform for greater community awareness and participation in civic processes, e-governance initiatives tend to emerge under a model of service delivery (Nuggehalli, 2009), from an ICT for development perspective, all municipalities can adopt effective egovernance for social and local economic development (Abrahams and Newton-Reid, 2008).

According to Debo (2013:18), government is the working together of the people in an organized setting. It is equally the methods, strategies, tactics ways and means of working together. As Herbert (1985), puts it in Okoli (2013:232), the participatory government employs decision making process is the heart of administration and the pumping centre which galvanizes other organizational units into activities. This is explained better by Herzberg (1950), in his Motivation-Hygiene Theory as captured by Ezeani (2006:142), where citizens (workers) showed that they are motivated, satisfied and at the end, maintain law and order when they are involved in the governance of the land.

According to them, the participatory government brings about the following:
a) Achievement
b) Recognition
c) Work itself
d) Responsibility and
e) Advancement.

The presence of the above in the lives of the people perhaps makes the people feel happy and as such, shun social restiveness and it brings about peace in the urban centres.

E-governance is capable of promoting participatory democracy at the grassroots level and providing riding board for citizen's involvement in governance, as it was upheld by Sachdeva (2002) that e-democracy is an effort to change the role of citizen from passive information giving to active citizen involvement. In an edemocracy the Government will be informing the citizen, representing the citizen, and encouraging the citizen

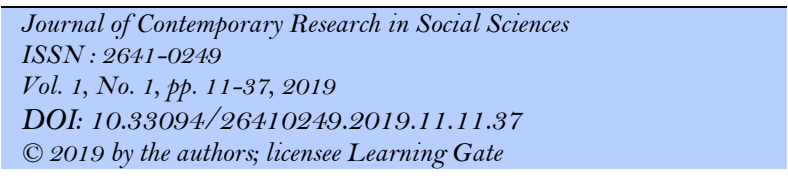


to vote, consulting the citizen and engaging the citizen in the Governance. Taking the citizens input about the various government policies by organizing an e-debate will further strengthen the e-democracy.

New technologies can support effective decentralization and expand its benefits. They create new relationships and enable collaborative work across time and distance. They create better conditions for the decentralization of resource management as Integrated Financial Information Systems (IFMS) allow for shared and timely management of information, traceable transactions, and the implementation of various accountability measures (Maswood, 2009). Corroboratively, Urban and rural divide can now be minimized through the application of ICT services, bridging the gap. However, governance is often quoted for urban/metropolitan areas, whether that governance reaches across the void, is where the innovation of governance mechanisms can be manipulated.

\section{vi. $\quad$ Creation of Link between the Central Government Departments}

Advances in Information Communication Technology (ICT) and the growing use of the ICT by individuals in organizations in the entire world has changed the face of the world, (Agbo, 2014, p.1).In the words of Abdulkareem (2015), the Government of Nigeria has been able to innovate and make ICT relevant to our needs. Of course, in the field of networking, the Government Secure Intranet (GSI) and puts in place, a secure link between the Central Government Departments.

According to Ojo (2013), by implementing e-governance systems, we can provide the possibility of closer interactions, government to government, government to public services, government to citizens, and public services to citizens. Electronic Governance (e-Governance) is the use of Information and Communication Technologies (ICT) for the planning, implementation, and monitoring of government programmes, projects, and activities (Crowley, 2008). E-Governance is expected to help deliver cost-effective and easy-to-access citizen services. It is defined as delivery of government services and information to the public using electronic channels (Baidyabati Municipality, 2012).

E-governance means using information and communication technologies (ICTs) at various levels of the government and the public sector and beyond, to enhance governance (Bedi et al., 2001; Holmes, 2001; OkotUma, 2000 cited in Palvia and Sharma, 2007). E-governance is a set of "technology-mediated processes" that are changing both the delivery of public services and the broader interactions between the citizens and Government.

\subsubsection{Areas/Aspects/Scope of Electronic Governance}

The areas, aspects or scope of e-governance according to Ojo (2013), revolve around e-registration, eparticipation, e-taxation, e-mobilization, e-education, e-service delivery, e-feedback, e-policing, e-planning, edebate and analyses of public financial statements.

\section{i. E-Governance in Education Sector}

In a democratic society such as Nigeria, civic education is bedrock through which sustainable democracy could be realized. The involves information relating to citizen's democratic exercises such as voting eligibility and sensitization towards citizen's political rights etc. The adoption of internet facilities may enhance the actualization of these various programmes that may benefit the citizens at the grassroots level in Nigeria. According to Norris (2002), democracy requires two-way communication as well as information, at regular intervals beyond elections, so that political leaders receive feedback and maintain contact with the grassroots. Many commentators who advocate 'strong' or 'direct' democracy commonly argue that these functions are not well served by e-governance, and this criticism has some value if judged by government websites alone. The opportunities for 'bottom up' interactivity in communicating with official departments are far fewer than the opportunities to read 'top down' information.

According to Danfulani (2013), recruitments and examinations in schools, ministries, departments, and parastatals are electronically done. Candidates apply online; write examination online via buying well secured scratch cards and their scripts marked electronically. Within days results of examinations are out and candidates told his fate. The practice wasn't like that before now; they were slow, esoteric, and manipulatable due to an excessive involvement of personnel rather than machines. This process also nips in the bud inconsistencies associated with age and other academic claims by candidates, issues very essential for recruitments. In each recruitment exercise especially into Nigerian Armed Forces, so many candidates are rejected or recruitment offer withdrawn because of phantom claims that contradicted regulations associated with the recruitments which are noticed due to the employment of e-governance.

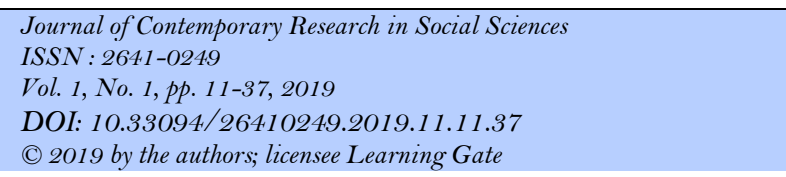


Porta (2010), argues that ICT can be used to extend access to education delivery techniques, to support the ongoing professional development of workers and facilitate education-related data collection and processing efforts in ways previously not possible. ICT infrastructure can provide a fundamental building block upon which whole sets of knowledge and information service and activities can be enabled. The emergence of ICT tools offers new opportunities to develop some of the critical early literacy skills, the development of which is. According to Adeogun (2003), ICT has broken the barrier of distance and location experienced by researchers which use to impede the growth of formal education.

\section{ii. E-Participation and Mobilization}

Following the level of insecurity in the urban centres, there is every need that there should be decentralization of urbanization derivable from the nature of prevention, which requires proximity actors to be implemented. It will empower the local authority to act in ameliorating insuring problem in the municipal areas. As a French Jurist, Baron Montesquieu (1748) in Okoli (2015:125), puts it, there would be an end of everything if the same person or body, whether of the nobles or of the people, were to exercise all three powers and everything is fused in the centre. Obviously, a central government, by definition is distant from the reality of cities and the various challenges of the people of the various neighbourhoods.

Sequel to the above, Onyishi (1996), as was captured by Okpata (2006), explains that government agencies/ sectors are extended to rural areas with the purpose of intervening in a reasonable extent, in the private needs of the people in order to expand the area of human development and prevent crime rate in the state. Since the government cannot prevent insecurity in the urban areas only by developing the areas, it, therefore, must decentralize development for the effective prevention of insecurity.

When decentralization takes place, the local authority will be encouraged to implement security policies as governments can be closer to citizen's needs and even more importantly, the people will be prepared to understand better their municipality and what is going on within it. Proximity is not only political. It is cognitive. Participation in local affairs becomes paramount in a democratic society; e-governance promotes citizens participation while the elected representative becomes more accessible through the provision of information communication technology.

The modern system of communication encourages citizens to be involved in local decision making. According to Hina (2007) successful e-governance mechanism can only operate through strong private and public participation. Trust and accountability will play a vital role in converting the potential to reality. Awareness is pivotal to create such participation, yet literacy plays an important role in obtaining it. ICT will provide that enabling environment.

The participatory approach must be translated within each process of e-government institution be it at the local or state level through horizontal and vertical integration. This participation would follow the earlier model where the business citizen, individual, marketplace, employees and institutions have direct access to government services, maximizing interaction through online transactions. One way of achieving such is through mandatory adaptation of offline financial services in a secure online framework thereby minimizing the cost to the government. Participation must occur through the electoral process as well as e-voting mechanism, ensuring democratic e-governance.

E-Mobilization may also foster citizen's participation in local decision making and community projects. For instance, the activities of the Community Development Association can be placed on the government data page, informing the citizens to participate in the communal project. This avenue will facilitate peoples participation in ensuring grassroots development.

\section{iii. E-Consultation}

The programmes of government become informative through the application of ICT at the grassroots level. When the activities of government are widely and popularly disseminated, it makes the citizens informed on the various programmes provided for sustainable grassroot development. Sier (2005) corroborates this argument that the increased availability of political information using e-governance is envisioned to improve participatory democracy.

The publication of information on the local policymaking process such as those that could be found in the minutes of meetings of the City Council, the city's legislative body, promotes accountability of elected officials to their electorate, thus enhancing their representative role. For the citizens, information on both the process and the outcome (resulting ordinances) may raise their appreciation of the policymaking process, including the role of their elected officials, which may, in turn, increase their participation in the selection of local leaders.

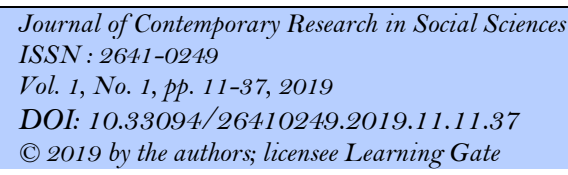


Consulting citizens through online polls and surveys facilitates direct feedback that could raise the quality of decision making and help promote the partnership.

\section{iv. $\quad$ E-Policing}

Security of lives and properties is the primary responsibility of any responsible government all over the world. Therefore, e-policing could be a platform for citizens to alert the security agency of the major issues related to security anywhere in the society and this will also facilitate adequate feedbacks. Wilson and Cox (2008), report that in a bit to prevent the rising crime and violence in the early 2000s, Oakland, California, voters passed the Violence Prevention and Public Safety Act of 2004, commonly referred to as Measure Y.

Measure $\mathrm{Y}$ is a 10-year, nearly $\$ 20$ million annual investment aimed at reducing violence through community-policing, violence-prevention, and other programs. After being aware of the security situation in an area (urban centre), the next step to take is community policing,, empowered by e-governance, where every individual uses electronic apparatus watch over criminals who may come to perpetrate any criminal activity in people's vicinities: homes, work places, street, worship centres and their environs. Be that as it may, the application of ICT/electronic system could be very beneficial in the security of lives and property of the people.

According to ADT (2011), the adoption of ICT facilities could aid/guide the people in protecting their lives and property at home and outside the home in the following ways:
a. Changing of Locks
b. Installation of Alarm System
c. Lighting Up of the Entrance to one's Home
d. Installation of Deadbolt Locks
e. Using of Metal Bars on Sliding Doors
f. Using of Interior Door Hinges

\section{v. E-planning}

Planning is very important for any organization to survive, be it private or public. According to Onah (2008, p.12), through planning, managers attempt to anticipate forces that will influence the future supply of and demand for employees. Planning perhaps is better done electronically. The planning is done electronically by the governmentsector however, involves informing the public of the policies and programmes of government before the final implementations, (Onah, 2008). The citizens, therefore, may provide advice and share their view towards government initiatives to enhance better outcomes through the use of internet. Accordingly, there are currently 4 major levels/aspects of E-government in municipal governments:

$\mathrm{x}$. The establishment of a secure and cooperative interaction among governmental agencies;

xi. Web-based service delivery;

xii. The application of e-commerce for more efficient government transactions activities;

xiii. Digital democracy.

These go along with 5 degrees of technical integration and interaction of users in the following ways:

- Simple information dissemination (one-way communication);

- Two- way communication (request and response);

- Service and financial transactions;

- Integration (horizontal and vertical integration);

- Political participation.

Other areas of E-governance include: E-debate, E-Coordination, E-taxation, E-Registration, Evoting and E-transaction, etc.

\subsection{Empirical Review}

Agbo (2014), researched 'Challenges of Information and Communication Technology Adoption in Abakaliki, Ebonyi State University, Ebonyi State, Nigeria.' The specific objectives of the study included to: Determine the level of ICT knowledge and usage among academic staff and students in Ebonyi State University, Ebonyi State-Nigeria for enhanced learning. Ascertain the extent to which funding constraints affect the adoption of Information Communication Technology facing Ebonyi State University, Ebonyi State, Abakaliki. To find out the extent to which inadequate power supply militate against adoption of ICT facilities inEbonyi State University, Ebonyi State, Abakaliki.TTo finds out the extent to which inadequate power

Journal of Contemporary Research in Social Sciences
ISSN : $2641-0249$
Vol. 1, No. $1, p p .11-37,2019$
DOI: $10.33094 / 26410249.2019 .11 .11 .37$
C 2019 by the authors; licensee Learning Gate


supply militates against adoption of ICTfacilities in Ebonyi State University, Ebonyi State, Abakaliki. Some of the findings in the study included: The level of ICT knowledge and usage among academic staff and students in Ebonyi State University, Ebonyi State is insufficient. Funding constraints affect the adoption of ICT facilities inEbonyi State University, Ebonyi State. The adoption of ICT facilities inEbonyi State University, Ebonyi State, is grossly inadequate. The researcher recommended as follow: The management ofEbonyi State University, Ebonyi State, Abakaliki should see the need for alternative sources of power supply and standby generators, inverters and batteries. The management ofEbonyi State University, Ebonyi State, Abakaliki should liaise with Corporate Organization and developmental partners to contribute to the growth and development of ICTs facilities in the University System. Effort should be made to establish ICT facilities inEbonyi State University, Ebonyi State, Abakaliki.

Emmanuel and Onwe (2014), carried research on 'Challenges of Information and Communication Technology (ICT) use in River State University of Science and Technology Library.' The objectives of the study include: To find out the type of ICT resources available to the library staff of RSUST. To examine the extent of use of ICT resources by the library staff of RSUST. To find out whether the library staff of RSUST are skilled in the use of ICT. The findings include that it is increasingly clear that information is the lifeblood of any academic system. The growth and application of new ICTs in the field of education has been discovered to be burdened with enormous difficulties. The researcher recommended the following: The University Authority should doggedly address the problem of poor ICT infrastructure and epileptic power supply by rejecting necessary funds into the system for acquisition of appropriate ICT resources and standby generators to ensure continuity of work in the case of power outage. ICT policy must be put in place and free hand should be given to the library department to run the library.

Nwuwa (2014), carried research on 'Application of ICT on Teaching in Ebonyi State University: A Study of some selected Departments in Ebonyi State.' The objectives of the study include to: Determine the degree to which infrastructure such as computer CD ROM Aaffects teaching of ICT courses in some selected Department in Ebonyi State University; Determine the relationship between internet connectivity and ICT teaching in some selected Departments in Ebonyi State University; Access the challenges of quality of ICT infrastructure on ICT Teaching effectiveness in Ebonyi State University. The findings include: The infrastructure such as computer CD ROM Aaffects teaching of ICT courses in some selected Departments in Ebonyi State University; there are some relationships between internet connectivity and ICT teaching in some selected Departments in Ebonyi State University; the quality of ICT infrastructure on ICT Teaching is not enough in Ebonyi State University. The researcher recommended that the ICT infrastructure in the University should be increased and improved for effective teaching and learning. The staff of Ebonyi State University should undergo training and retraining on ICT.

Fathi, jahani \& Azadmanesh (2010), carried astudy on Application of ICTs in Teaching and Learning at University Level: The case of Shahid Beheshti University. The findings of the study revealed that Information and communication technologies (ICTs) are a diverse set of technological tools and resources used for creating, storing, managing and communicating information. For educational purposes, ICTs can be used to support teaching and learning as well as research activities including collaborative learning and inquiring. The recommended the following: The possible domains of using ICT in curriculum decision-making should be developed in highest level.Obstacles of using ICT in curriculum development should be worked against at university level.Facilitatingfactors and essential supports needed for application of curriculum development of higher education should be developed.

Bakkabuindi (2011), carried out a study on Individual Characteristics as Correlates of Use of ICT in Makerere University. The study used survey design to sought to investigate- links between use of ICT with six individual characteristics, namely interaction with ICT change agents, ICT training, cosmopolitanism, age, gender and income level. The researcher recommended that appropriate measure should be made towards putting in place ICT change agents in all units in the University. There should also be training leading for the possession of ICT qualifications and special ICT to help the staff perform better. There should be the provision of institutional ICT so that the financially less privileged can also access ICT facilities.

Adeyemo (2010), carried a study on the impact of information and communication technology ICT on teaching and learning of physics. The study investigated the impact of information and communication technology on teaching and learning of physics. The respondents used or the study were one hundred and fifty-seven (157) physics students and two (2) physics teachers drawn randomly from two senior secondary schools from each of the five educational districts out of the six educational districts available in Lagos State. The researcher formulated three null hypotheses and tested at 0.05 level of significant. The instruments used

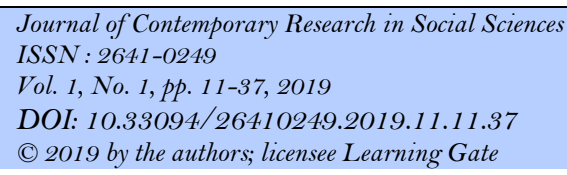


for the study were information and communication Technology impact on teaching and learning questionnaire. The data collected were analyzed using simple percentage and chi-square. The researcher found out that ICT has great impact on teaching and learning of physics. Also, the introduction of ICT makes learning of physics so interesting for the students. The researcher, therefore, recommended that there should always be adequate training the manpower in the public institutions. The government should also make money available for the development of ICT facilities in the higher institutions.

Alzaydi (2018), carried research on, 'A review of Service Quality and Service Delivery: Towards a Customer Co-production and Customer-integration Approach.' The main purpose of the study is to provide researchers with an overview of the service quality and delivery domain, focusing on the inclusion of customer integration. Specifically, the paper concentrates on service quality (including quality measurement), the service environment, controls and their consequences. In the design/methodology/approach, the researcher adopted a comprehensive review of the literature is conducted, analyzed and presented. The following form the findings in the study: The review shows that service delivery is both complex and challenging, particularly when considering the unique characteristics of services and the high level of customer involvement in their creation. The facilitation, transformation and usage framework identifies how failures can occur at each stage of service delivery, beginning with the characteristics of the service environment, while control theory offers insights into the formal and informal controls that may be applied in the facilitation and transformation stages, which may reduce the likelihood or extent of such failures.

Jaykumar (2014), researched on, 'Service Delivery Quality Improvement Models: A Review.' The main purpose of the study is to critically analyze various delivery quality improvement models and to identify and to identify the hypothetical approach of various models under each facto that are significant to hotel industry or not. In the design/methodology approach, this study was designed into three phases: the mapping stage, analysis stage and concluding stage. The hypothesis of the study shows that there is a positive but not significant effect of shared vision on organizational performance. Service mode can judge service quality as well as customer satisfaction and it was applied and used in the banking sectors of China. There is also the prove that trust and commitment has a positive association with satisfaction because of trust and commitment services antecedents to satisfaction. The implication of the study is that effort was made in the study to review various service delivery quality improvement models. These models present a useful framework for quality of service delivery. Through critical review, the study analyzed various models under each factor from different authors to identify hypothetical approach of the models significant to hotel industry. The paper provides a new gate way for the upcoming researchers. The study discovered a new direction in service delivery improvement research and offers theoretical and practical aid to researchers and practitioners in providing a direction for service delivery improvement. The gap in literature discovered in the study is that future research needs to replicate this research to establish the reliability of the models used in the study and to address some of the limitations of the study.

Ferrreira, Santos, Azevedo, Goncalves and Olieveira (2018), research on, Performance Indicators and Accountability in Portuguese Public Universities: Socio-Economic Perspective.' The objective of the study was on a drive from the following research problems: what factors influence the disclosure of performance indicators by the PPU in the management report? The research questions include: 1 . Do the PPU disclose the performance indicators imposed by law? 2. Do the PPU disclose performance information beyond what is required? 3. What are the factors that may influence the level of PPU disclosure? In the research design, the researcher started by analyzing the websites of all PPU, trying to verify the existence of available information regarding the financial years of 2010,2011,2012 and 2013. The researcher summarized table 1 the result of the analysis. The findings in the study include: the use of sample of the PPU indicates that not all universities make available on their sites the management report or activities. It is increasingly necessary to measure the performance in the PPU. Performance indicators in the, based on accountability, can be seen as a driving force for the effectiveness and efficiency of the management of PPU.

Bongwon, Chi, Aniket and Bryan (2018), wrote on, 'Lifting the Veil: Improving Accountability and Social Transparency in Wikipedia with WikiDashboard.'The researchers emphasized collaborative knowledge building to have become a highly successful paradigm for creating, finding, and consolidating content online, with popular examples such as Digg.com, del.icio.us, and Wikipedia. The main objective of the study was to open up ways of improving social accountability and transparency worldwide. The researchers adopted a descriptive survey design in the study, as Simple Random Technique was employed in the study. The theory of Social Translucence was adopted. The finding made in the study was that improving social transparency can increase the ability of readers to use the histories of writers to judge the quality of the content, and also

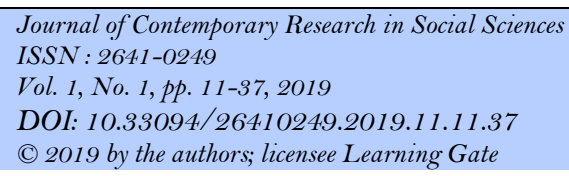


possibly encourage writers to be more responsible. There could be the increase in accountability and social transparency by surfacing hidden editing information through an unobtrusive 'dashboard' embedded in each Wikipedia page.

\section{Research Design}

The design adopted in this study is a descriptive survey design. It involves systematic collection and presentation of data given a clear picture of a particular action and correlation.

\subsection{Area of Study}

This study focuses on some selected Ministries in Ebonyi State, namely:

\section{Population of the Study}

The total population of this study is 456 derivable from the Ministryof Information and State Orientation, Ministry of Finance, Ministry of Health and Ministry of Education, allin Ebonyi State. The detail is in the table below:

Table-1

A table showing the Population of the Study.

\begin{tabular}{|l|l|l|l|}
\hline $\mathbf{S} / \mathbf{N}$ & Ministries & Population & Percentage (\%) \\
\hline 1 & Information and State Orientation & 123 & 27 \\
\hline 2 & Finance & 123 & 27 \\
\hline 3 & Health & 112 & 25 \\
\hline 4 & Education & 98 & 21 \\
\hline $\mathbf{5}$ & Total & $\mathbf{4 5 6}$ & $\mathbf{1 0 0}$ \\
\hline
\end{tabular}

\subsection{Sampling Techniques}

The sampling technique used in this study is Simple Random Technique where the respondents were picked randomly.

\subsection{Sampling Size Determinations}

The sample size of population was determined using TARO Yemeni formular.

$$
N \frac{n}{1+N(e) 2}
$$

Where: $\mathrm{n}=$ desired sample

$\mathrm{N}=$ total population

Therefore, a total number of one hundred and sixty eight (168) questionnaire items were distributed to the respondents as drawn from the population of 290 .

\section{$\underline{n=456}$}

$$
1+456(0.05) 2=\underline{456}
$$

$1+456(0.0025)=\underline{456}$

$1+1.14$

$=\underline{456}$

$$
2.14=213.0=\mathrm{N}=213
$$

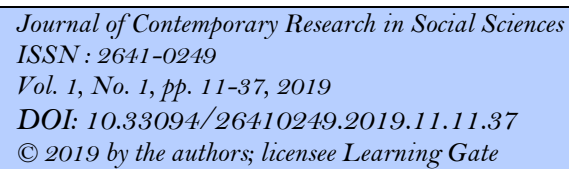




\subsection{Research Instrument}

The instrumentation adopted in generating data in this study was questionnaire where questions were given to the respondents respectively following the research questions.

\subsection{Validity of Instrument of Data Collection}

Face (expert) validity method was used to validate the instruments in this study to certify the suitability of the questionnaire items. The test instrument was submitted to the supervisors and other the experts in electronic governance, service delivery,measurement and statistics to correct and/or validate.

\subsection{Validity of Instrument of Data Collection}

The researcher adopted Pilot Test for the validation of the instrument of data collection, where there was a random selection of a small number of sample from the population. There is to know how consistent the respondent was with their answers. Meanwhile, a Pilot experiment also called a pilot study, isaccording to Hulleu (2007), a small scale preliminary study conducted in order to evaluate feasibility, time cost, adverse events and effect size in an attempt to predict an appropriate sample size and improve upon the study design prior to reference of a full-scale research project.

\section{Data Presentation and Analysis}

Table 2.

Questionnaire Distribution

\begin{tabular}{|c|c|c|c|c|c|c|c|}
\hline $\mathbf{S N}$ & Description & $\begin{array}{l}\text { No of Questionnaire } \\
\text { Items }\end{array}$ & $\%$ & $\begin{array}{c}\text { No } \\
\text { Returned }\end{array}$ & $\%$ & $\begin{array}{c}\text { No } \\
\text { Unreturned }\end{array}$ & $\%$ \\
\hline 1 & Political Appointees & 35 & 16.4 & 4 & 4 & 31 & 26 \\
\hline 2 & Health Workers & 42 & 20 & 18 & 19 & 24 & 20 \\
\hline 3 & Lecturers & 44 & 21 & 34 & 36 & 10 & 8 \\
\hline 4 & Accounting officers & 35 & 16.4 & 20 & 21 & 15 & 13 \\
\hline 5 & Journalists & 29 & 14 & 10 & 11 & 19 & 16 \\
\hline 6 & Contractors & 28 & 13 & 8 & 9 & 20 & 17 \\
\hline 7 & Total & 213 & 100 & 94 & 100 & 119 & 100 \\
\hline
\end{tabular}

Source: Field Survey 2018

From the table above, the researcher distributed 35 questionnaire items to the Political Appointees. Among the 35 questionnaire items, the persons/respondents that returned their responses were 4 and while those who did not return any response were equally 31 . Also, 42 questionnaire items were given to the Health Workers and 18 persons/respondents returned their responses and 10 respondents did not return any response. For the Lecturers, 44 questionnaire items were given to them and 34 of them returned responses while 10 respondents did not return any response. For the Accounting Officers, 35 questionnaire items were given to them and 20 of them returned their responses while 15 of them did not return any response. For the Journalists, 29 questionnaire items were given, 10 items were returned and 19 items were not returned. For the Contractors, 28 questionnaire item were distributed, 8 items were returned, and 20 items were not returned. In totality, 213 questionnaire items were distributed and 94 respondents returned their responses while 119 respondents did not return any response.

Table 3.

A table showing the extent the adoption of Electronic Governance aids record keeping/tracking of eventsin the Ministries in Ebonyi State.

\begin{tabular}{|l|l|l|l|l|l|l|l|l|l|l|l|l|}
\hline S/N & Questionnaire Item & $\mathbf{S A}$ & $\mathbf{\%}$ & $\mathbf{A}$ & $\mathbf{\%}$ & $\mathbf{S D}$ & $\mathbf{\%}$ & $\mathbf{D}$ & $\mathbf{\%}$ & $\mathbf{U}$ & $\mathbf{\%}$ & $\mathbf{X}$ \\
\hline 1 & $\begin{array}{l}\text { E-Governance helps to keep, invoke } \\
\text { and revoke the history and tradition of } \\
\text { the Ministries in Ebonyi State. }\end{array}$ & 34 & 36 & 29 & 34 & 14 & 14 & 15 & 15 & 3 & 3.1 & \\
\hline 2 & $\begin{array}{l}\text { E-Governance helps to review the } \\
\text { current, reliable/accurate records } \\
\text { capable of improving the activities of } \\
\text { the Ministries in Ebonyi State. }\end{array}$ & 35 & 37 & 28 & 30 & 15 & 16 & 16 & 17 & 1 & 1 & \\
\hline
\end{tabular}




\begin{tabular}{|c|c|c|c|c|c|c|c|c|c|c|c|}
\hline 3 & $\begin{array}{l}\text { E-Governance significantly aids } \\
\text { budget tracking in the Ministries in } \\
\text { Ebonyi State. }\end{array}$ & 37 & 37 & 26 & 28 & 16 & 17 & 14 & 15 & 2 & 2 \\
\hline 4 & $\begin{array}{l}\text { E-Governance helps to review the } \\
\text { area where there is gap in the } \\
\text { workforcein the Ministries in Ebonyi } \\
\text { State. }\end{array}$ & 34 & 36 & 29 & 34 & 14 & 14 & 15 & 15 & 3 & 3.1 \\
\hline 5 & $\begin{array}{l}\text { E-Governance reduces cost and stress } \\
\text { involved in record keeping and record } \\
\text { gatheringin the Ministries in Ebonyi } \\
\text { State. }\end{array}$ & 33 & 35 & 29 & 31 & 12 & 13 & 17 & 18 & 3 & 3.1 \\
\hline
\end{tabular}

Source: Field Survey, 2018.

\section{Table Analysis}

E-Governance helps to keep, invoke and revoke the history and tradition of the Ministries in Ebonyi State.

In the table above, thirty four (34) respondents with $36 \%$ strongly agreed that E-Governance helps to keep, invoke and revoke the history and tradition of the Ministries in Ebonyi State while twenty nine (29) respondents with $31.0 \%$ agreed. Ten (10) respondents with $4 \%$ strongly disagreed while fifteen (15) respondents with $16 \%$ disagreed and three (3) respondents with $3.1 \%$ gave no response.

E-Governance helps to review the current, reliable/accurate records capable of improving the activities of the Ministries in Ebonyi State.

Thirty five (35) respondents with $37 \%$ strongly agreed with the assertion that E-Governance helps to review the current, reliable/accurate records capable of improving the activities of the Ministries in Ebonyi State while twenty eight (28) respondents agreed. The respondents who strongly disagreed are fifteen (15) in number with $16 \%$ and sixteen (16) respondents with $17 \%$ just disagreed while one (1) respondents with $1 \%$ did not answer.

\section{E-Governance significantly aids budget tracking in the Ministries in Ebonyi State.}

In the table three above, thirty seven (37) respondents with $39 \%$ strongly agreed that E-Governance significantly aids budget tracking in the Ministries in Ebonyi Statewhile twenty six (26) respondents with $28 \%$ disagreed with the assertion sixteen (16) respondents with $17 \%$ strongly disagreed while fourteen (14) respondents with $15 \%$ disagreed and two (2) respondents with $2 \%$ did not give any response.

Table 4.

The table showing the extent the adoption of electronic governance encourages accountability and transparency in the Ministries in Ebonyi State.

\begin{tabular}{|l|l|l|l|l|l|l|l|l|l|l|l|l|}
\hline S/N & Questionnaire item & SA & \% & A & \% & SD & \% & D & \% & U & \% & X \\
\hline 6 & $\begin{array}{l}\text { The Accountability and } \\
\text { transparencycushioned by } \\
\text { e-governance } \\
\text { couldsignificantly reduce } \\
\text { corruption in the } \\
\text { Ministries in Ebonyi State. }\end{array}$ & 41 & 23 & 24.4 & 10 & 11 & 19 & 20 & 3 & 3.1 & \\
\hline 7 & $\begin{array}{l}\text { There could be rapid } \\
\text { development as cushioned } \\
\text { by accountability and } \\
\text { transparency which exist } \\
\text { when there is e- } \\
\text { governance in the } \\
\text { Ministries in Ebonyi State. }\end{array}$ & $\begin{array}{l}\text { When there is e- } 30 \\
\text { governance there could } \\
\text { beaccountability and } \\
\text { transparency, giving room }\end{array}$ & 32 & 25 & 27 & 15 & 16 & 21 & 22.3 & 3 & 3.1 \\
\hline 8
\end{tabular}




\begin{tabular}{|c|c|c|c|c|c|c|c|c|c|c|c|c|}
\hline & $\begin{array}{l}\text { tothe availability of fund } \\
\text { for the implementation of } \\
\text { project and programme in } \\
\text { the Ministries in Ebonyi } \\
\text { State. }\end{array}$ & & & & & & & & & & & \\
\hline 9 & $\begin{array}{l}\text { The existence of e- } \\
\text { governance gives brings } \\
\text { about accountability and } \\
\text { transparency, leading to } \\
\text { drastic reduction of } \\
\text { corruption in the } \\
\text { Ministries in Ebonyi State. }\end{array}$ & 29 & 31 & 21 & 22.3 & 17 & 18 & 23 & 24.4 & 2 & 2.1 & \\
\hline 10 & $\begin{array}{l}\text { The accountability and } \\
\text { transparency e-governance } \\
\text { brings significantly leads } \\
\text { to the development in the } \\
\text { Ministries in Ebonyi State. }\end{array}$ & 95 & 44.1 & 80 & 37.3 & 22 & 11.1 & 12 & 5.6 & 10 & 4.6 & 4.1 \\
\hline 11 & $\begin{array}{l}\text { The accountability and } \\
\text { transparency arising from } \\
\text { the existence of e- } \\
\text { governance significantly } \\
\text { reduces wastes, } \\
\text { carelessness and } \\
\text { misappropriationin the } \\
\text { Ministries in Ebonyi State. }\end{array}$ & 80 & 42.3 & 70 & 37.0 & 20 & 10.5 & 10 & 5.2 & 9 & 4.7 & 4.22 \\
\hline
\end{tabular}

E-Governance helps to review the area where there is gap in the workforce in the Ministries in Ebonyi State.

In the table above, thirty four (34) respondents with $36 \%$ strongly agreed that E-Governance helps to review the area where there is gap in the workforce in the Ministries in Ebonyi Statewhile twenty nine (29) respondents with $31.0 \%$ agreed. Ten (10) respondents with $4 \%$ strongly disagreed while fifteen (15) respondents with $16 \%$ disagreed and three (3) respondents with $3.1 \%$ gave no response.

E-Governance reduces cost and stress involved in record keeping and record gathering in the Ministries in Ebonyi State.

The assertion that E-Governance reduces cost and stress involved in record keeping and record gathering in the Ministries in Ebonyi Staterecorded thirty three (33) responses with 35\% for those who strongly agreed while twenty nine (29) respondents with 31\% agreed, twelve (12) respondents with $13 \%$ strongly disagreed while seventeen (17) respondents with $18 \%$ disagreed. Nevertheless, three (3) respondents with $3.1 \%$ recorded no responses.

\section{Table Analysis}

The Accountability and transparency cushioned by e-governance could significantly reduce corruption in the Ministries in Ebonyi State.

In the table above, thirty nine (39) respondents with $41 \%$ strongly agreed that the Accountability and transparency cushioned by e-governance could significantly reduce corruption in the Ministries in Ebonyi Statewhile twenty three (23) respondents agreed to that. On the other hand, ten (10) respondents with $11 \%$ strongly disagreed with the assertion as nineteen (19) respondents disagreed. Then, just three (3) respondents returned no response.

There could be rapid development as cushioned by accountability and transparency which exist when there is e-governancein the Ministriesin Ebonyi State.

In responding to the above assertion, thirty one (31) respondents with $33 \%$ strongly agreed that there could be rapid development as cushioned by accountability and transparency which exist when there is egovernance in the Ministries in Ebonyi Statewhile twenty seven (27) respondents with 29\% agreed to that. On

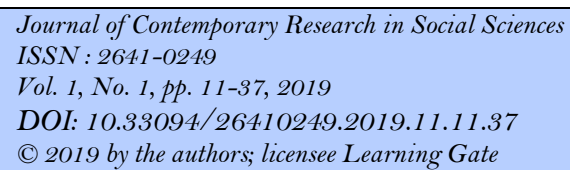


the other hand, fourteen (14) respondents with $15 \%$ strongly disagreed with the assertion as twenty (20) respondents with $21 \%$ disagreed. Then, two (2) respondents with $2.1 \%$ gave no response.

When there is e-governance, there could be accountability and transparency, giving room to the availability of fund for the implementation of project and programme in the Ministries in Ebonyi State.

Thirty (30) respondents with $32 \%$ strongly agreed that when there is e-governance, there could be accountability and transparency, giving room to the availability of fund for the implementation of project and programme in the Ministries in Ebonyi Statewhile twenty five (25) respondents with $27 \%$ agreed. Fifteen (15) respondents with $27 \%$, nevertheless, strongly disagreed to the assertion while twenty one (21) respondents with $16 \%$ disagreed to the assertion and three (3) respondents with $3.1 \%$ never gave any response.

The existence of e-governance gives brings about accountability and transparency, leading to drastic reduction of corruption in the Ministries in Ebonyi State.

The respondents that strongly agreed that the existence of e-governance gives brings about accountability and transparency, leading to a drastic reduction of corruption in the Ministries in Ebonyi Stateare twenty nine (29) having $31 \%$ while those that agreed are twenty one (21) in number with $22.3 \%$. However, those that strongly disagreed are seventeen (17) 18\% while twenty three (23) respondents just disagreed and two (2) respondents did respond at all.

The accountability and transparency e-governance brings significantly leads to the developmentin the Ministries in Ebonyi State.

Ninety five (95) respondents with $44.1 \%$ strongly agreed with the assertion that the accountability and transparency e-governance brings significantly leads to the development in the Ministries in Ebonyi State. The respondents who strongly disagreed are twenty one (21) in number while $11.1 \%$ and twelve (12) respondents with $5.6 \%$ just disagreed while ten (10) respondents with $4.6 \%$ did not answer.

The accountability and transparency arising from the existence of e-governance significantly reduce wastes, carelessness and misappropriation in the Ministries in Ebonyi State.

In table three above, eighty (80) respondents with $42.3 \%$ strongly agreed that the accountability and transparency arising from the existence of e-governance significantly reduces wastes, carelessness and misappropriation in the Ministries in Ebonyi State while seventy (70) respondents with $37.0 \%$ disagreed with the assertion, twenty (20) respondents with $10.5 \%$ strongly disagreed while ten (10) respondents with $5.2 \%$ disagreed and nine (9) respondents with $4.7 \%$ did not give any response..

Table 5.

A table establishing the extent the Adoption of Electronic Governance encourages Quality Service Deliveryin the Ministries in Ebonyi State.

\begin{tabular}{|c|c|c|c|c|c|c|c|c|c|c|c|c|}
\hline $\mathbf{S} / \mathbf{N}$ & Questionnaire Item & $\mathbf{S A}$ & $\%$ & $\mathbf{A}$ & $\%$ & SD & $\%$ & $\mathbf{D}$ & $\%$ & $\mathbf{U}$ & $\%$ & $\mathbf{X}$ \\
\hline 12 & $\begin{array}{l}\text { Electronicgovernance enhances } \\
\text { quality service delivery through } \\
\text { increased time andfinancial } \\
\text { managementamong workersin the } \\
\text { Public Service in Ebonyi State. }\end{array}$ & 29 & 31 & 26 & 28 & 20 & 21.2 & 16 & 17 & 3 & 3.1 & \\
\hline 13 & $\begin{array}{l}\text { E-governanceenables the } \\
\text { acquisition ofmore electronic } \\
\text { knowledge needed for quality } \\
\text { service deliveryin the Public Service } \\
\text { in Ebonyi State. }\end{array}$ & 28 & 30 & 27 & 29 & 19 & 20.2 & 17 & 18.3 & 3 & 3.1 & \\
\hline 14 & $\begin{array}{l}\text { E-governance helps toreduce } \\
\text { unnecessarybureaucracy/bottled } \\
\text { neck/red-tapismwhich militates } \\
\text { against quality service deliveryin } \\
\text { the Public Service in Ebonyi State. }\end{array}$ & 30 & 32 & 24 & 26 & 23 & 24.4 & 15 & 16 & 2 & 2.1 & \\
\hline
\end{tabular}




\begin{tabular}{|l|l|l|l|l|l|l|l|l|l|l|l|l|}
\hline 15 & $\begin{array}{l}\text { E-governance significantly proffers } \\
\text { solutions to } \\
\text { differentproblemsconfronting the } \\
\text { quality service delivery in the } \\
\text { Public Service in Ebonyi State. }\end{array}$ & 44.1 & 80 & 37.3 & 21 & 11.1 & 12 & 5.6 & 10 & 4.6 & 3.72 \\
\hline 16 & $\begin{array}{l}\text { E-governance helps tostrengthen } \\
\text { global relationship/linkbetween } \\
\text { civil servants for improved service } \\
\text { delivery in Nigeria. }\end{array}$ & 29 & 31 & 26 & 28 & 20 & 21.2 & 16 & 17 & 3 & 3.1 & \\
\hline
\end{tabular}

Source: Field Survey, 2018

\section{Table Analysis}

Electronic governance enhances quality service delivery through increased time and financial management among workers in the Public Service in Ebonyi State.

The respondents who strongly agreed with the assertion that Electronic governance enhancesquality service delivery through increased time and financial management among workers in the Public Service in Ebonyi State who engage on research in the Public Service in Ebonyi Stateare twenty nine (29) with 31\% while twenty six (26) respondents with $28 \%$ agreed with the assertion. On the other hand, the respondents who strongly disagreed are twenty (20) recording $21.2 \%$ while those who just disagreed are sixteen (16) with $17 \%$. However, three (3) respondents did not return any response and they recorded $3.1 \%$.

E-governance enables the acquisition of more electronic knowledge needed for quality service delivery in the Public Service in Ebonyi State.

Twenty eight (28) respondents with 30\% strongly agreed that E-governance enables the acquisition of more electronic knowledge needed for quality service deliveryin the Public Service in Ebonyi Statewhile twenty seven (27) respondents with $29 \%$ agreed. Nineteen (19) respondents with $20.2 \%$ strongly disagreed while seventeen (17) respondents with $18.0 \%$ disagreed and three (3) respondents with $3.1 \%$ returned no response.

E-governance helps to reduce unnecessary bureaucracy/bottled neck/red-tapism which militates against quality service delivery in the Public Service in Ebonyi State.

Thirty (30) respondents with $32 \%$ strongly agreed that E-governance helps to reduce unnecessary bureaucracy/bottled neck/red-tapism which militates against quality service delivery in the Public Service in Ebonyi Statewhile twenty four (24) respondents with $26 \%$ agreed. Twenty three (23) respondents with $24.4 \%$ strongly disagreed while fifteen (15) respondents with $16 \%$ disagreed and two (2) respondents with $2.1 \%$ returned no response.

E-governance significantly proffers solutions to the different problems confronting quality service delivery in the Public Service in Ebonyi State.

The respondents who asserted that E-governance significantly proffers solutions to the different problems confronting quality service delivery in the Public Service in Ebonyi Statewere thirty two (32) with $34 \%$ while twenty five (25) respondents with $26 \%$ agreed with the assertion. On the other hand, the respondents who strongly disagreed are twenty one (21) recording $22.3 \%$ while those who just disagreed are twelve (12) with $13 \%$. However, four (4) respondents did not return any response and they recorded $4.2 \%$.

\section{E-governance helps to strengthen global relationship/link between civil servants for improved service delivery in Nigeria.}

The respondents who strongly agreed with the assertion that E-governance helps to strengthen global relationship/link between civil servants for improved service delivery in Nigeriaare twenty nine (29) with $31 \%$ while twenty six (26) respondents with $28 \%$ agreed with the assertion. On the other hand, the respondents who strongly disagreed are twenty (20) recording $21.2 \%$ while those who just disagreed are sixteen (16) with $17 \%$. However, three (3) respondents did not return any response and they recorded $3.1 \%$. 


\section{Discussion}

The adoption of Electronic Governance aids record keeping/tracking of events in the Ministries in Ebonyi State.

According to the International Standard Organization (2001), record keeping is the created, receiving, and maintaining information as evidence and information by an organization or a person. In pursuance of a legal obligation or in the business transaction. For Shepherd (2006), record keeping is the process of undertaking a certain activity by a person or a work group in the course of attaining an expected business outcome. As the International Standard Organization (2001), puts it, record management/keeping is the management/keeping that ensures the efficiency. In his words, Ajewole, (2000), referred to record keeping as the filling of record which is the processing of arranging and storing records in an orderly manner so that they could be traced without difficulty when needed.

As explained by Okpata (2006:250), record is an assemblage of facts and figures which when harnessed into information propels/shapes the immediate or later action or response of the receiver in a particular area at a particular point in time. Notably, the security challenged areas usually include security information in the records made available to the people for consumption. Such record or information brought to the public domain day by day to help them avert security disaster and protect their lives and property is the awareness campaign that must be strengthened and taken to every nook and cranny of a city if security will be boosted in such areas.In the same vein, Ezrali andEwulonu (2011), record keeping is a way of safeguarding official documents systematically, such that they may be accessible at any time required.

Good record keeping system clearly shows the arrangement of files folders containg different records and the indexes for easy filling and retrieval

Be that as it may, the adoption of electronic governance enables good record keeping in an organization. This is because it is only the use of Information Communication Technology (ICT), that enable a better record keeping considering the attributes of a good record keeping system mentioned above.In the words of Hare and Mcleod (1997), the introduction of ICT has tremendously improved record keeping world over. Meanwhile, the changes in technology have continually geared the improvement in record keeping in our institutions.

\section{The adoption of electronic governance encourages accountability and transparency in the Ministries in Ebonyi State}

The adoption of electronic governance encourages accountability and transparency in the Ministries in Ebonyi State. According to Omebe (2015), accountability promotes capacity building and infrastructural development and speaks volume on the existence of good governance in a state. In his words, Johari (1989:280), through the adoption of e-governance, the legislative and the executive armsare better empowered to enforce accountability on the workers in the ministries in the state. The government functionaries perhaps, have the obligation of making sure that they remain accountable. In that case, contracts carried out to conform to the money appropriated. In a variation, the account given could conform to the account tendered after implementation of the projects and programmes. That of course, is accountability.

In his words, Onah (2010), outlines some of the national programmes that accountability is needed for their execution to include: National Poverty Eradication Programme (NAPEP), Expanded Programme on Immunization (EPI), National Programme on Humanization, Structural Adjustment programmes (SAP), National Action Committee on Aids (NACA), and Integrated Rural Development Programme (IRDP) etc. These and many more programmes and projects need oversight function monitoring and evaluation by the legislature because of their interests on them in one way or another. There could be accountability and transparency in implementing these programmes and projects when there is electronic governance in place.

According to Mandel (2012), specific examples of executive officers gaining improper benefits as a result of inadequate/lack of proper accountability and transparencyhave giving room to misuse of discretionary funding for operating expenses and pork barrel projects. Distribution of discretionary funds can be based on party relationships, given to favour beneficiaries, and used for kickbacks. The misappropriation of these monies results in poorly conceived projects, unfavaourable contracts, and injury to the environment and natural resources. These take place because of inadequate usage of Information Communication Technology in form e-governance.

Akomolede and Bosede (2012:61), therefore, expounds the above observation by opining that the legislature is truly not independent while exercising oversight functions on the executive and therefore, is often incapacitated from acting as the watchdog of the executive on finance. Thus, the inordinate ambition of

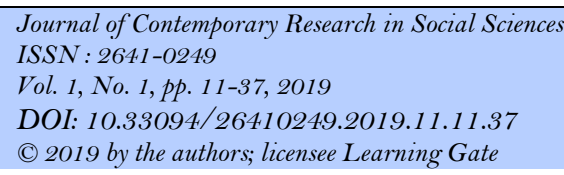


members and leadership of the legislative houses often see them hob-knobbing with the executive such that valuable time for financial assessment is lost in the process of lobbying for juicy contracts.

In his words, Aguda (2012), associated himself with those who maintained that in the absence of egovernance, there could be corruption in government due to financial mismanagement in the state. He noted that while bribery and corruption could seriously undermine any system of government, there could be accountability and transparency if there is e-governance in the state. Meanwhile, Okereke (1986), cited by Onah (2010), explains that the executive couldavoid the act of bribery and corruption become accountable if there could be e-governance in the state. As such, the government could afford to do the following:

- Comparing the actual and planned capital and operational west and highlight cost differences by type and inputs, timing and direction;

- Calculating the real production costs and comparing it with the actual product price.

- Comparing the actual and planned sales and receipts to check whether they relate to estimates and finding the actual cost-return relationship of the project.

\section{The adoption of electronic governance enhances Quality Service Delivery in Ebonyi State Bureaucracies/Ministries}

The knowledge of Information Communication Technology, metamorphosing to the adoption of electronic governance enhances quality service delivery in the ministries in Nigeria in many ways. This is because it exposes the staff of the ministries to the current trends and makes them fit and ready to solve problems using different kinds of knowledge gathered from ICT. AsObasi (2000, p. 1), has it, the accumulation of knowledge in our daily lives is a process that involves separate methods as well as a combination of methods. There is why Nwankwo (2014, p. 150), emphasized that in the course of transferring knowledge, for quality service delivery, some of the electronic gadgets are important. Such gadgets include laptops, palmtops, desktops, Projectors, Film strips, Micro-projectors and Opaque projector. The adoption and usage of these electronic gadgets facilitate quality service delivery in any civil service.

Overhead projector According to Shahriza et al (2007), the website is seen as an increasingly important reading source. In the words of Okpata and Ukeje (2010), e-governance has impacted greatly on effective research in many ways. According to Islam (2007), the application of web-based information retrieval trends of researchers is ever increasing and the electronic material will eventually replace the traditional library and users need not go there to find and collect information they need.

ICT infrastructures truly provide a fundamental building block upon which whole sets of knowledge and information service and activities can be enabled. The emergency ICT tools offer new opportunities to develop some of the critical early literacy skills for optimal performance. According to Adeogun (2003), ICT have broken the barrier of distance and location existing among workers as it concerns sharing of ideas and principles which enhances quality service delivery. Information Communication Technology has also had profound impacts on the tasks and skills of workers in both pattern andquality delivery.Rapid development of ICT has led to many changes in the responsibilities of many civil servants. The traditional/analogue way of working/service thereby becomes inappropriate, obsolete and unacceptable in the world today.

\section{Major Findings}

The following are the major findings in this study:

i. The adoption of electronic governance in running the affairs of the ministries brings about effective service delivery in the state. It helps in defining and re-defining the current vision and mission of the government.

ii. The adoption of electronic governance curtails the level of corruption and encourages accountability and transparency in governance since it is a mechanism for carrying out proper internal and external auditing in government.

iii. The adoption of electronic government enhances quality service delivery in the Ministries in Ebbonyi State.

iv. The adoption ofelectronic governance bythe government of Ebonyi State couldimprove real budget tracking system in the state.

v. Employment of qualitative and quantitative manpower who are experienced in the electronic governance could make the Civil Service better in Ebonyi State.

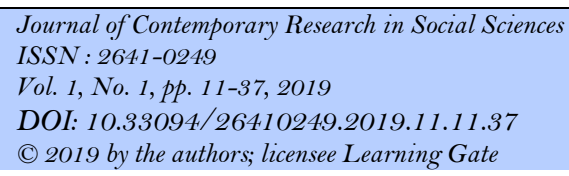




\section{Conclusion}

The goal of electronic governance is to be able to have the ability to access \& interact with the world. Developing countries have many opportunities to better themselves through e-governance. E-governance helps different governments to walk with the world. The information revolution has ushered in a new paradigm of administrative efficiency and effectiveness leading to improved delivery of public services necessary for economic development, peace and stability of a country. The adoption of electronic governance facilitates the administration in the public service since it enhances the quality of public services. It also brings about efficient, cost-effective and convenience and make administrators more transparent and. Moreover, some challenges pose serious impediments to the adoption and application of ICT in the operations of the Nigeria Public Service.

\section{Recommendations}

- Following the findings made in this study, the researcher recommends as follows:

- The managements of the ministries in Ebonyi State should adopt the use of ICT facilities in running the affairs of the ministries for effective service delivery in the state.

- There should also be the adoption of electronic governance in Ebonyi State because it will help in ensuring accountability and transparency since it is a mechanism for carrying out proper internal and external auditing in government.

- The government should adopt the use of electronic government in the ministries in Ebonyi State because it will help facilitate the formulation of strategies for the project and programme implementation in the state.

- Since the evaluation of job performance is very important in the ministries, the government of Ebonyi State should adopt the use of electronic government for better job evaluation in the state.

- The government should make sure that there is adequate power supply throughout Ebonyi State to facilitate the electronic activities in the state.

- The government of Ebonyi State should also adopt electronic governance to help the managements of the ministries in Ebonyi State carry out proper and adequate internal and external auditing in the state.

- The government should employ both qualitative and quantitative workforce who are experienced in the electronic governance in the ministries so that the programmes and projects of the government will always be effectively and efficiently carried out.

\section{References}

ADT (2011). 10 Tips to Improve Your Home's Security. Retrieved from https://blog.allstate.com/wpcontent/uploads/2011/11/515518221.jpg Share

Adayemo, S. A. (2010). 'The Impact of Information Communication Technology (ICT) ON Teaching and Learning of Physics,'International Journal of Education Research and Technology, 1(2): 48.

Agbo, E. E. (2014). Challenges of Information and Communication Technology Adoption in Abakaliki, Ebonyi State University, Ebonyi State, Nigeria, beingan Unpublished Dissertation Presented in the Department of Public Administration, Ebonyi State University, Abakaliki.

Akbar A (2004). Automating Government with e-Governance; Linux J.

Amstrong, E. (2005). Integrity, Transparency and Accountability in Public Administration: Recent Trends, Regional and International Developments and Emerging Issues, Economic and Social Affairs, (online).

Atuloma, B. C. (2011). Perceived Records Management Practice and Decision Making Processamong Universityy Administrators in Nigeria, Library Philosophy and Practice, 4(1): 1-7.

Ayemi, A. B. (2000). High Bureaucracy and the use of Information for Police Formulation and Implementation in the Federal Civil Service of Nigeria, (1988-19998). An Unpublished Ph.D Thesis, presented at University of Benin, Nigeria. pp: 102.

Bak, N. (2004). Completing Your Thesis. Retrieved from www.vanschaik.com/ebook/522041a6df491

Baidyabati Municipality (2012). E-Governance Retrieved from www.baidyabatimunicipality.org/egov.

Barman H (2009). E-Governance in India: How Citizens Benefit?

Backus M (2011). E-Governance and Developing Countries; Research Report No. 3, April. 
Bakkabulind, F. E. (2011). Individual characteristics as Correlates of use of ICT Impacts on Schools in Europeer, European Schoolnet.

Bongwon, S., Chi, E. Aniket, K, and Bryan, A. P. (2018). Lifting the Veil: Improving Accountability and Social Transparency in Wikipedia with Wiki. Dashboard: Palo Alto Research Centre Inc.

Cox, R. J. (2001). Managing Records as Evidence and Information, Westport: Quorum Book.

Crowley, M. (2008). E-Governance, Prenatal Care in Utah, published by Center for Public Policy \& Administration, University of Utah, 4(6).

Cyrille, N. I. (2010). The management of personnel records in the presisent's office: Public Service Management of Tanzania, an unpublished Dissertation, presented inRecords management and information, Moi University.

Danfulani J (2013). E-governance: a weapon for the fight against corruption in Nigeria; an online publication. Retrieved from onsaharareporter.com.

Dawes S (2008). 'The Evolution and Continuing Challenges of E-Governance,'Public Administration Reviere, Special Issue.

Debo, A. (2013). 'Legislative Oversight Functions and Accountability,' an online publication.

Emmanuel, V. O. and Onwe, O. U. (2014). 'Challenges of Information and Communication Technology (ICT) use in River State University of Science and Technology Library,'Ebonyi State College of Education, Ikwo, Journal of Social Engineering, Awka: Love- Isaac ConsultatancyService, 2 (3).

Ezeali, B. and Ewulonu U. (2011). Office management and Organization, Onisha: Chambers Books Ltd.

Ezeani, E. O. (2006). Fundamentals of Public Administration. Enugu: Snaap Press Ltd.

Fathi, J. and Azadmanesh (2010). 'On Application of ICT in Teaching and Learningat University Level: The case of Shahid Beheshti University, TOJET,'The Turkish Online Journal of Educational Technology Aapril, 2010, 9(2).

Ferrreira, A. Santos, C. Azevedo, G. Goncalves, J. and Olieveira, J. (2018). Performance Indicators and Accountability in Portuguese Public Universities: Socio-Economic Perspective, International Financial Reporting Standards and New Directions in Earnings Management.

Hina S (2007). E-Governance Is Good Governance.

Ikeagwuani, M. N. (2001). Practical Secretarial Duties. Onitsha: Adason Educational Publishers.

Illoanusi, N. O. and Osaugwu, .C. C. (2006). 'ICT Diffusion and Uptake in Nigeria Tertiary Educational Institutions:Trends, Perspectives and Possibilities,'African Journal of Computer and ICTs -Special Issue on ICTs in the African Environment, 1(1):141.

Imeremba, D. U. (2005). Fundamentals of Database Management, Enugu:John Jacobs Classic Publisher.

International Standard Organization (2001). Information and Documentation-Record management, Part 1. Geneva: Case Postale.

Jaja, T. G. (2012). Legislative Oversight and Public Accountability in Nigeria: A Study of Rivers State House of Assembly, 1999-2011. An Unpublished Ph.D Thesis, University of Nigeria, Nsukka.

Johari, J. C. (1989). Principles of Modern Political Science, New Delhi: Sterling Publishers Private Ltd.

Kadir, Abdul-Azeez A. (n.d.). Legislative Oversight Failure, Catalyst for Corruption. Retrieved from http://www.gamji.com/article8000/NEWS8636.htm.

Lifehacker.com/5873325/the-bestbudget.

Longe, A. E. (2000). Management Information System: Its Problems and Prospects Within the Federal Civil Service, an unpublished Lecture Delivered in Kwara State.

Maswood S (2009). The Concept and Legal Aspects of E governance: The United Arab Emirates' Perspective, The Electronic Transaction Conference.

Nnamani, L. C. (2009). Politics of Development and Underdevelopment. Enugu: John Jacob's Classic Publishers Ltd.

Norris, P (2000). E-Governance. Retrieved from http/www.hks.havard.edu/digitalch6.pdf.

Nuggehalli R (2009). Building an Alternative E-Governance Model: Lessons from e-Gram in Gujarat.

Nwanekezi, A. U. , Bruno, O. and Oragwu, A. A. (2011). 'Reviewing Science Education Curriculum through the Integration of ICT Practices: Implication for Scientific Literacy. Journal of Emerging Trends in Educational Research and Policy Studies, 2(1): 53.

Nwizu, G. (1997). Organization: Basic Problems, Principles and Theories. Okikwe: Marco printing Press.

Nwizu, G. (1999). Eminent Administrative Thinkers from Taylor to the Present Day. Enugu: John Jacob's Classic Publishers Ltd.

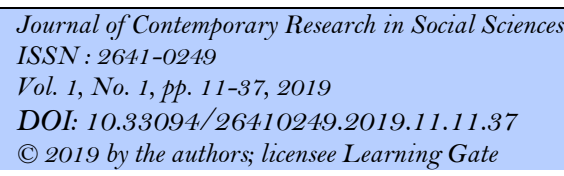


Nwoba, A. E. (2013). Security of Public Records. A SeminarPaper Presented on Public Service Effectiveness.

Nwuwa, M. F. (2014). Teaching in Ebonyi State University: A Study of some selected Departments in Ebonyi State. An Unpublished M.Sc Dissertation in the Department of Public Administration, Ebonyi State University, Abakaliki.

Okoli, F. C. (2013). Foundations of Government and Politics. Abakaliki: De Oasis Communications \& Publishers $(\operatorname{pg} 125)$.

Okpata, F.O. (2006) Bureaucratic Communication and Information Management. Enugu: Jones Communication.

Onah, F.O. (2008). Human Resource Management. 2nd Edn. Enugu: John Jacob’s Classic Publishers Ltd.

Onah, F.O. (2010). Managing Public Programmes and Projects, 2nd Edn., Enugu: John Great AP Express Publishers Ltd.

Palvia, S. C. J., Sharma, S. S. (2007).. E-Government and E-Governance: Definitions/Domain Framework and Status around the World. Computer Society of India.

Rahman, H. (2011). Local E-Government Management: A Wider Window of E-Governance. IGI Global.

Sabina, P. M. M. (2004).'Freedom of Information, Records Management and Good Governance, any Symbolic Relationship. Journal of the Eastern.

Sachdeva, S. (2002). E-Governance Strategy in India; White Paper on E-Governance Strategy in India.

Shade, W. P. (1991). Record Management and Information Issues. New York: Office, Office Publication Inc.

Sherpard, E. (2006). 'Why are record in Public Sector Organization Asset,'Record Mnagement Journal, 16(1): 6 of City Government Websites; Philippine Journal of Development SIAR 135 (60) Second Semester 2005, 32(2).

Sutcliffe, P. (2000). 'Building the Corporate Memory in the E-environment. Records Management Journal, $139(2): 51$. UNESCO (2005). E-Governance Capacity Building.

Unwaifo, S. O. (2004). 'Management Use of Records in Delta State University, Abraka, Nigeria. RecordsManagement Journal, 14(2): 85-89.

Wamukoya, J. \& Mutula, S. M. (2005). 'Capacity building Requirements for E-Records Management: the Case of East and Southern Africa,'Records Management Journal, 15(2): 71-79.

Wilson, J. M. and Cox, A. G. (2008). Community Policing and Crime: The Process and Impact of Problem-Solving in Oakland, Santa Monica: the RAND Corporation.

Zakaria, Z. (2001). Factors Related to Information Communication Technology Implementation in the Malaysian Ministry of Education Polytechnic, An Unpublished Doctoral Thesis, Virginia Polytechnic Institute and State University, 2001. 